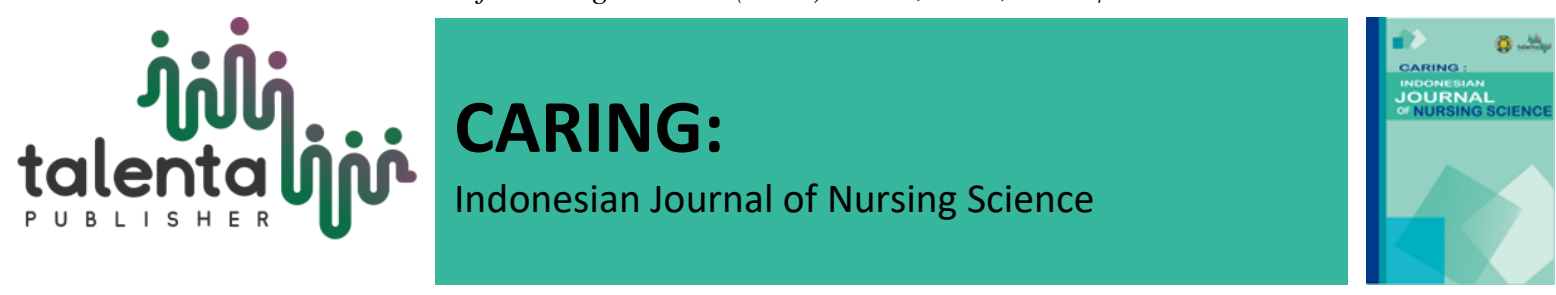

\title{
The Caring Attitude of Nurses and Mother's Motivation for Child Immunization Attendance
}

\author{
Mathalena Simamora ${ }^{1}$, Jek Amidos Pardede ${ }^{2}$, Farhana Irwan ${ }^{3}$ \\ ${ }^{12,3}$ Lecturer of Psychiatry and Community Nursing Department. Nursing Study Program, Sari Mutiara \\ Indonesia University, Indonesia
}

\begin{abstract}
Nurses' caring attitude is the core in nursing standard practices that is mandatory for all nurses. In practicing caring attitudes, nurses show their empathy and care to patients in order to positively affect patients' healing process. Furthermore, caring attitudes by nurses to mothers are expected to increase mothers' motivation to attend to child immunization at public health centers regularly. The objective of the study was to identify the relationship between nurses' caring attitude and the motivation of mothers in regularly taking their children for immunization at Belawan Public Health Center. This study employed correlational descriptive method using cross sectional approach. A total number of 52 mothers with the children of 0-12 months old served as research population. Sampling technique was total sampling technique in this study. By performing spearman rank statistical test, it was obtained that there was a strong correlation between caring attitude of nurses and mothers' motivation for child immunization attendance $(p=0.005 ; \mathrm{r}=0.551)$. It is concluded that caring attitude of the nurses improve the motivation of mothers for child immunization attendance. It is suggested that nurses should practice caring while serving mother patients in order to increase awareness and internal motivation among mothers to bring their children to Public Health Center for immunization.
\end{abstract}

Keywords: caring attitude of nurses; mothers' motivation; immunization attendance.

Received 24 May 2020 | Revised 9 June 2020 | Accepted 10 June 2020

\section{Introduction}

In response to Healthy Indonesia Programs with Family Approach, the Indonesian government determines 12 primary indicators of family health status. One of the programs is Expanded Program on Immunization (EPI) to support infants in receiving a complete basic immunization (Cahyono, 2016). The purpose of immunization for children is to improve body immunity toward certain kinds of disease. Immunity in children is influenced by several factors including high levels of antibodies at the time of immunization, potential of the injected antigens, and time interval of immunization schedule. These factors influence the effectiveness of immunization in forming immunity among children (Hidayat, 2015).

According to Basic Health Research (2013) stated that the percentage of immunization attendance in Sumatera Utara Province in 2013 was 67.2\%, while the data released in 2018 showed that the percentage is increased to $78.4 \%$. Meanwhile, data per district area showed that 
the percentage of immunization attendance at the coastal area in Medan Municipal, at Belawan Public Health Center was relatively low. It is necessary to figure out the factors underlying low participation of mothers in immunization program and the role of health workers for a good interaction establishment with mothers during their visit to health center.

Healthy communication between health workers and their colleagues as well as health workers with patients should be maintained in order to increase mothers' visits to public health center for immunization. It requires health workers' skills in order to improve the work performance (Nursalam, 2014). The nurses should perform a nursing practices with a caring attitude (Calong \& Soriano, 2018), to fulfill the patients' medical needs and expectations professionally (Aligood, 2017).

Firmansyah et al. (2019) proposes that caring is the nurses' attitude shown through attention, appreciation, and a willingness to fulfill their medical needs with empathy. An act of caring attitude from nurses may be in the form of ability to maintain good relationship with mothers through good communication and caring behaviors during their visits to Public Health Center. Mayseless (2016) distinguishes caring attitudes into several categories, namely, caring ties, caring relationship, caring occasion/moment, and caring behavior. Caring behavior is defined as an action of showing empathy, giving attention and priority to other people, respecting ones' self-esteem, focusing on humanity and commitment to prevent degrading health condition (Nursalam, 2014). Nurses as health professionals should have caring attitude in themselves in order to change mothers' perception about immunization and increase their motivation to bring their children to take immunization regularly at Public Health Center. It is expected that the nurses' caring attitudes will positively impact the mother's motivation to bring the children for regular immunization attendance.

\section{Research Methods}

This research was a correlational descriptive study with cross sectional approach. A total number of 52 mothers with children aged 0-12 months were included as research population. Total sampling technique served as sampling technique. A set of questionnaires, of which the validity and reliability had been tested (Cronbach's alpha $=0.665$ ), was administered to assess caring attitude of nurses. Furthermore, another set of questionnaires was also used to assess mothers' motivation, with Cronbach's alpha $=0.889$. The data were analyzed by performing Spearman Rank correlational test.

\section{Result and Discussion}

The research result showed that respondents were in the range of 25-35 years of age (63.4\%), were majorly Islam (67.3\%), most of them graduated from senior high school (76.9\%), 32.7\% of the respondents were Bataknese, while Javanese was $32.7 \%$. The specific detail as follows. 
Table 1. Frequency Distribution of the Mother's Characteristics

\begin{tabular}{lcc}
\hline Characteristics & n & \% \\
\hline Age & & \\
< 25 years old & 3 & 5.8 \\
25-35 years old & 33 & 63.4 \\
>35 years old & 16 & 30.8 \\
\hline Religion & & \\
Islam & 35 & 67.3 \\
Christian & 17 & 32.7 \\
\hline Education & & \\
Primary & 3 & 5.8 \\
Junior High & 6 & 11.5 \\
Senior High & 40 & 76.9 \\
Bachelor & 3 & 5.8 \\
\hline Ethnic Group & & \\
Malay & 8 & 15.4 \\
Acehnese & 6 & 32.7 \\
Bataknese & 17 & 7.7 \\
Minangnese & 4 & 32.7 \\
Javanese & 17 & \\
\hline
\end{tabular}

In addition, the caring attitude of nurses in the study was majority good (81.1\%) as the table shown below.

Table 2. Frequency Distribution of the Nurse's Caring Attitude

\begin{tabular}{ccc}
\hline Nurses' Caring Attitude & n & \% \\
\hline Good & 43 & 81.1 \\
Poor & 9 & 17.0 \\
\hline
\end{tabular}

And, according to the research result the majority of mothers who visited Belawan Public Health Center had a high level of motivation to bring their children for immunization as the table below.

\section{Table 3. Frequency Distribution of Mother's Motivation of Child Immunization}

\begin{tabular}{ccc}
\hline Mothers' Motivation & n & \% \\
\hline High & 42 & 79.2 \\
Low & 10 & 18.9 \\
\hline
\end{tabular}

Based on the research result above, the result of Spearman Rank Test which obtained $p$ value= $0.005(\mathrm{p}<0.05)$. This value indicates that the variables of nurses' caring attitude and mother's motivation have a positive correlation. Furthermore, the $r$ value $=0.551$ shows that there was a strong correlation between nurses' caring attitude and motivation of mothers toward immunization attendance at Belawan Public Health Center. 
Table 4. The Relationship between the Nurse's Caring Attitude and the Mother's Motivation for Immunization.

\begin{tabular}{ll}
\hline & Mother's Motivation toward Immunization Attendance \\
\hline Nurses' Caring Attitude & $r=0.551^{* *} \quad p=0.005$ \\
\hline
\end{tabular}

\section{Caring Attitude of Nurses}

The result of data analysis obtained that caring attitude of nurses in this study was majorly good. According to the questionnaire sheet, it was obtained that nurses practiced caring behavior to their clients. Caring behaviors such as giving attention and affection to children, providing clear information about immunization program to mothers, and introducing themselves before administering immunization made mothers feel supported and cared. The result of this study is in line with Sumiyati (2016) who reported that good communication will result in good relationship between nurses and mothers. This study is also supported by Zalmiati \& Nuryati (2017) denoting that nurses who show positive attitudes and behaviors while giving healthcare services is an important factor on patient satisfaction. It is because each individual has different sensitivity level. Therefore, it is suggested that before giving healthcare services to clients, nurses as health professionals should introduce themselves and attain trust from patients and build a good relationship with them.

Caring attitude is the central in nursing practices since it is a dynamic approach that can be carried out by nurses to improve their attention and empathy to patients as their clients (Sartika \& Nanda, 2011). Caring attitude is the core in nursing practices (Pardede \& Simamora, 2020). Caring is also described as an ideal moral in nursing, including will to care, determination to care, and practice to care (caring). Based on personal opinion of researchers, nurses' behaviors in maintaining good communication will always result in comfortable feeling in clients that eventually help their recovery process. According to Pardede, et al (2020). Caring attitude is not only about practicing caring through physical actions but also through facial expressions.

\section{Mothers' Motivation}

This study found that the motivation of mothers who visited Belawan Public Health Center was high. Through responses from the questionnaire sheet, it was obtained that mothers were satisfied with the services during immunization sessions, were willing to bring their children to receive immunization, and were comfortable with attentive gestures from nurses at the public health center. This study is in line with Andriyani (2017) reporting that the proportion of respondents who were satisfied with services from health workers was $95.4 \%$, indicating that positive behaviors while giving healthcare services to clients can improve clients' satisfaction toward services and healthcare provider. 
According to Sutrisno (2013), a component that can be used to assess motivation level is valence of responses toward outcomes, such as satisfaction; whether or not the valence inclines to be positive or neutral. High level of motivation occurs when clients receive services that exceed their expectation. This theory supports the results of this study. Based on the responses of the respondents, it was found that mothers' motivation to visit public health center together with their children for immunization are influenced by the way nurses administer immunization, services given by nurses to their children, and nurses' skills when giving immunization. These cause mothers to have trust toward nurses and bring their children to public health center for immunization.

\section{The Relationship between Caring Attitude of Nurses and Mothers' Motivation}

The results from data analysis showed that there was a significant correlation between caring attitude of nurses and mothers' motivation $(\mathrm{p}=0.005)$. The result from spearman rank calculation obtained $r=0.551$ indicating a strong relationship between caring attitude of nurses and mothers' motivation toward immunization attendance. The results show that the more nurses show caring attitude the higher the level of motivation of the mothers in visiting public health center for children immunization.

The result of the present study is also supported by Erfianto (2015) proposing that caring is not only about behaviors, but also values or beliefs in nurses that motivate them to perform caring nursing practices. Caring can also be defined as action in giving physical nursing intervention for clients' safety. According to Umam (2012), motivation is regarded as an internal stimulus or impulse in individuals that drives their soul and behaviors. It is a driving force that controls how individuals purposefully act or behave.

\section{Conclusion}

There is a significant relationship between caring attitude of nurses and motivation of mothers toward immunization attendance at Belawan Public Health Center, with $p=0.005(<\alpha 0.05)$ and correlational strength, $r=0.551$. It is necessary to always improve nurses' caring attitude through various ways, such as positive thinking. By always thinking positively, nurses give examples to others, not only to clients but also their colleagues, to always see something from a more positive perspective. Besides, nurses should also develop their empathy to others and understand their emotional states, so that nurses are able to personally approach and affect others to a more positive direction. They may also motivate other people to accept their condition and be content despite their difficult situation, so that their health condition will be improved. By practicing caring attitude, nurses create a supportive environment to their patients which is good for their healing process, protect and improve patients' mental condition resulting from their poor health condition. Caring attitude from nurses will positively affect clients so that clients can follow the instructions and suggestions from nurses. 


\section{Acknowledgement}

Author would like to thank the respondents for all valuable data provided in this research.

\section{Conflict of Interest}

There is no conflict of interest in this research result.

\section{REFERENCES}

[1] Alligood, M. R. (2017). Nursing theorists and their work-e-book. Elsevier Health Sciences.

[2] Andriani, A. (2017). Hubungan Mutu Pelayanan Kesehatan Dengan Kepuasan Pasien Diruangan Poli Umum Puskesmas Bukittinggi. Jurnal Endurance, 2(1), 45-52. doi: http://doi.org/10.22216/jen.v2i1.461

[3] Cahyono, S., Nugroho, H. A., \& Rahayu, A. (2011). Gambaran Perilaku Caring Perawat Di Ruang Nusa Indah Rumah Sakit Bhakti Wira Tamtama Semarang. http://jurma.unimus.ac.id/index.php/perawat/article/view/33/33.

[4] Calong, K. A. C \& Soriano, G. P. (2018). Caring Behavior and Patient Satisfaction: Merging for Satisfaction. International Journal of Caring Sciences, 11(2), 697. https://www.internationaljournalofcaringsciences.org/docs/9_1soriano_original_10_2.pdf

[5] Erfianto, E. (2015). Hubungan Perilaku Caring Perawat Dan Mutu Pelayanan Dengan Tingkat Kepuasan Pasien Peserta Bpjs Di Puskesmas Leksono I Kabupaten Wonosobo (Doctoral dissertation, Universitas Muhammadiyah Purwokerto). http://repository.ump.ac.id/5873/

[6] Firmansyah, C. S., Noprianty, R., \& Karana, I. (2019). Perilaku Caring Perawat Berdasarkan Teori Jean Watson di Ruang Rawat Inap. Jurnal Kesehatan Vokasional, 4(1), 33-48. https://doi.org/10.22146/jkesvo.40957

[7] Hidayat, A. (2015). Pengantar Konsep Keperawatan. Edisi 2. Jakarta: Salemba Medika.

[8] Mulyani, S., Paramastri, I., \& Priyanto, M. A. (2008). Komunikasi dan Hubungan Terapeutik Perawat-Klien Terhadap kecemasan Pra Bedah Mayor. Berita Kedokteran Masyarakat, 24(3), 151. doi: https://doi.org/10.22146/bkm.3592

[9] Mayseless, O. (2016). Caring and meaning in psychotherapy. In Clinical Perspectives on Meaning (pp. 363-381). Springer, Cham.

[10] Nursalam. (2014). Manajemen Keperawatan Aplikasi dalam praktik Keperawatan Profesional. Edisi 4. Jakarta : Salemba Medika

[11] Pardede, J. A., \& Simamora, M. (2020). Caring Perawat Berhubungan dengan Kecemasan Orangtua yang Anaknya Hospitalisasi. Jurnal Penelitian Perawat Profesional, 2(2), 171-178. https://doi.org/10.37287/jppp.v2i2.93

[12] Pardede, J., Saragih, M., \& Simamora, M. (2020). Tipe Kepribadian Berhubungan dengan Perilaku Caring Perawat. Jurnal Keperawatan Silampari, 3(2), 707-716. https://doi.org/10.31539/jks.v3i2.1207 
[13] Ramadhan, I. N. (2017). Hubungan Pengetahuan Dan Sikap Caring Dengan Perilaku Caring Perawat Pada Pasien Di Ruang Rawat Inap Kelas Iii Bangsal Barokah Dan Inayah Rs Pku Muhammadiyah Gombong (Doctoral dissertation, STIKES Muhammadiyah Gombong). http://elib.stikesmuhgombong.ac.id/709/

[14] Riskesdas (2013). Profil kesehatan Indonesia, Kementerian Kesehatan RI. https://pusdatin.kemkes.go.id/resources/download/pusdatin/profil-kesehatanindonesia/profil-kesehatan-indonesia-2013.pdf

[15] Riskesdas (2018) Hasil Utama. Kementerian Kesehatan Badan Penelitian dan Pengembangan Kesehatan. https://www.kemkes.go.id/resources/download/infoterkini/hasil-riskesdas-2018.pdf

[16] Sartika, Nanda. (2011). Konsep Dasar Caring. http://www.pedoman.news.com. Diakses pada tanggal 10 April 2019.

[17] Sumiyanti, N. M., \& Dalem, G. A. P. (2016). Strategi Komunikasi Perawat Dalam Meningkatkan Kepuasan Pasien Di Instalasi Rawat Inap Rumah Sakit Umum Daerah Wangaya Kota Denpasar. Jurnal Kajian Ilmu Komunikasi, 12(1). http://ejournal.undwi.ac.id/index.php/ilkom/article/download/168/149

[18] Sutrisno, (2013). Managemen Sumber Daya Manusia, Edisi Pertama, Jakarta : Kencana

[19] Umam, K. (2012). Perilaku Organisasi. Bandung: Pustaka Setia.

[20] UNAIR. (2016). Tingkatkan Cakupan Imunisasi Indonesia.http://news.unair.ac.id/2016/0 3/08/tingkatkan-cakupan-imunisasiindonesia/. Diakses pada tanggal 10 April 2019

[21] World Health Organization, (2018). Immunization coverage : Fact Sheet. Diakses dari https://www.who.int/en/news-room/fact-sheets/detail/immunization-coverage. pada tanggal 10 April 2019

[22] Zalmiati \& Nuryati. E. (2017). Perilaku Caring Perawat Meningkatkan Kepuasan Keluarga Pasien Penderita $\quad \mathrm{Tb}$ Paru. http://download.garuda.ristekdikti.go.id/article.php?article=1021646\&val=15612\& title 